\title{
Compartment-specific pH monitoring in Bacillus subtilis using fluorescent sensor proteins: a tool to analyze the antibacterial effect of weak organic acids
}

\author{
Johan W. A. van Beilen and Stanley Brul* \\ Department of Molecular Microbial Physiology, Swammerdam Institute for Life Sciences, University of Amsterdam, Amsterdam, Netherlands
}

\section{Edited by:}

Nuno Pereira Mira, Instituto Superior

Técnico, Institute for Biotechnology and Bioengineering, Portugal

\section{Reviewed by:}

Harold J. Schreier, University of Maryland Baltimore County, USA Peter Setlow, University of Connecticut Health Center, USA

\section{${ }^{*}$ Correspondence:}

Stanley Brul, Department of Molecular Microbial Physiology, Swammerdam Institute for Life Sciences, University of Amsterdam, Science Park 904, 1098 XH Amsterdam, Netherlands e-mail: s.brul@uva.nl

\begin{abstract}
The internal $\mathrm{pH}\left(\mathrm{pH}_{\mathrm{i}}\right)$ of a living cell is one of its most important physiological parameters. To monitor the $\mathrm{pH}$ inside Bacillus subtilis during various stages of its life cycle, we constructed an improved version (IpHluorin) of the ratiometric, $\mathrm{pH}$-sensitive fluorescent protein pHluorin by extending it at the $5^{\prime}$ end with the first $24 \mathrm{bp}$ of comGA. The new version, which showed an approximate $40 \%$ increase in fluorescence intensity, was expressed from developmental phase-specific, native promoters of $B$. subtilis that are specifically active during vegetative growth on glucose $\left(P_{\text {ptsG }}\right)$ or during sporulation $\left(P_{\text {spoll }}, P_{\text {spollID }}\right.$, and $\left.P_{\text {sspE }}\right)$. Our results show strong, compartment-specific expression of IpHluorin that allowed accurate $\mathrm{pH}_{\mathrm{i}}$ measurements of live cultures during exponential growth, early and late sporulation, spore germination, and during subsequent spore outgrowth. Dormant spores were characterized by an $\mathrm{pH}_{\mathrm{i}}$ of $6.0 \pm 0.3$. Upon full germination the $\mathrm{pH}_{\mathrm{i}}$ rose dependent on the medium to 7.0-7.4. The presence of sorbic acid in the germination medium inhibited a rise in the intracellular $\mathrm{pH}$ of germinating spores and inhibited germination. Such effects were absent when acetic was added at identical concentrations.
\end{abstract}

Keywords: bacterial spore formers, spores, spore germination, intracellular pH, GFP, pHluorin, weak organic acids, uncouplers

\section{INTRODUCTION}

The internal $\mathrm{pH}\left(\mathrm{pH}_{\mathrm{i}}\right)$ of living cells plays a fundamental role in many chemical reactions. Many intracellular enzymes show optimal activity and stability in a narrow $\mathrm{pH}$ range near neutrality. Furthermore, in many organisms proton gradients are required for the greater part of ATP synthesis while uptake systems often depend on the proton gradient over the cell membrane (Krulwich et al., 1998, 2011; Slonczewski et al., 2009). In the model eukaryote Saccharomyces cerevisiae, $\mathrm{pH}_{\mathrm{i}}$ was found to be a signal controlling growth (Orij etal., 2011). Gene expression as a response to glucose starvation was found to be mediated by changes in the $\mathrm{pH}_{\mathrm{i}}$, through the protonation state-dependent binding of a transcription factor to membraneassociated phosphatidic acid (Young et al., 2010). In multicellular eukaryotes $\mathrm{pH}_{\mathrm{i}}$ is thought to be important during growth and differentiation (Cruciat et al., 2010). In prokaryotic organisms, the relationships between $\mathrm{pH}_{\mathrm{i}}$ and growth and development have not been studied extensively (Padan and Schuldiner, 1987).

Because of its various well-described differentiation modes, $B$. subtilis is generally considered to be the bacterial model organism for cellular differentiation. The best described mode of differentiation of this Gram-positive prokaryote is sporulation, with the pathways controlling sporulation understood in great molecular detail (Eichenberger et al., 2004; Steil et al., 2005; Wang et al., 2006). Germination is less well understood, but Keijser et al. (2007) have shown that this too, is a carefully orchestrated process. We reasoned that in analogy to eukaryotes, $\mathrm{pH}_{\mathrm{i}}$ could be a global regulator, as well as an indicator of the metabolic and energetic state of the cell. To gain further insight in the putative $\mathrm{pH}_{\mathrm{i}}$ dynamics of these differentiation processes, we studied the $\mathrm{pH}_{\mathrm{i}}$ of the mother cell and fore-spore independently. During sporulation the development of the $\mathrm{pH}_{\mathrm{i}}$ in the mother cell and the nascent forespore may also give insight in the level of independence of the two cells.

In $B$. subtilis, the $\mathrm{pH}_{\mathrm{i}}$ of the developing pre-spore is generally assumed to drop to $\mathrm{pH}=6.0-6.4$ during sporulation (Magill et al., 1994). The drop in $\mathrm{pH}$ causes a decrease in activity of phosphoglycerate mutase (PGM), which catalyses the conversion of 3-phosphoglycerate (3-PGA) to 2-phosphoglycerate. The reduced activity of PGM causes the accumulation of 3-PGA in the prespore. B. subtilis spores are metabolically dormant and contain no measurable ATP or glucose that could act as energy source during spore germination (Singh et al., 1977; Magill et al., 1996). It is assumed that the accumulated 3-PGA serves as an initial carbon and energy source for the cell.

The cell's $\mathrm{pH}_{\mathrm{i}}$ can be measured with various methods. Ideally, intracellular $\mathrm{pH}$ measurements should be conducted in systems containing Good's buffers (Good etal., 1966; Ferguson et al., 1980), to minimize the effect of the cell's surrounding (unless desired). The probe used to measure $\mathrm{pH}$ should maintain accuracy over the $\mathrm{pH}$ range assessed. In addition, both the presence of the probe itself in a cell as well as the detection method applied should have minimal effect on cell physiology. Currently used techniques include the distribution of radiolabeled membrane-permeant weak acids, ${ }^{31} \mathrm{P}$ nuclear magnetic resonance 
(NMR), fluorescent dyes (e.g., carboxyfluorescein, carboxyfluorescein diacetate, and succinimidyl ester; Ugurbil et al., 1978; Booth, 1985; Bulthuis et al., 1993; Magill et al., 1994; Breeuwer et al., 1996; Leuschner and Lillford, 2000). These methods have the advantage that no genetic modification is required and in the case of fluorescent dyes, single cell measurements are possible (Slonczewski et al., 2009). Weak acid dyes or reporters may alter the $\mathrm{pH}_{\mathrm{i}}$ and are therefore difficult to use accurately, and may require many treatment and incubation steps before measurement. ${ }^{31} \mathrm{P}$ NMR and radiolabeled compounds require extensive cell handling and high cell density, which also disturb cell physiology. Another useful method is the use of fluorescent proteins [green fluorescent protein (GFP) derivatives]. This does require the organism to be genetically accessible but allows direct, fast, and localized $\mathrm{pH}$ measurements. In our lab, we have successfully used ratiometric pHluorin (Miesenböck et al., 1998) for a number of years in S. cerevisiae (Orij et al., 2011; Ullah et al., 2012), and more recently also in B. subtilis (Ter Beek, 2009). However, the codon usage of pHluorin was not optimized for use in $B$. subtilis. Our initial experiments suggested that our results might benefit from an increase in fluorescence intensity. This might be achieved by improving translation initiation (Veening et al., 2004). We therefore fused the first eight amino acids of comGA to pHluorin (Veening et al., 2004), as this was shown to improve the signal strength of cyan fluorescent protein (CFP) and yellow fluorescent protein (YFP). The $\mathrm{pH}$-dependent ratiometric fluorescent properties of IpHluorin were not affected by this fusion. To monitor the $\mathrm{pH}_{\mathrm{i}}$ of both the mother cell and the pre-spore, ratiometric GFP-based IpHluorin was expressed from a number of developmental phase-specific native promoters of B. subtilis (Hilbert, 2004).

Expression of IpHluorin resulted in strong, compartmentalized, and cell type-specific signals. This allowed us to monitor the $\mathrm{pH}_{\mathrm{i}}$ during growth and sporulation, in both pre-spore, mother cell and mature spore, as well as during spore germination. Effects of the addition of sorbic and acetic acid on the $\mathrm{pH}_{\mathrm{i}}$ of germinating spores are described.

\section{MATERIALS AND METHODS}

\section{STRAINS AND GROWTH CONDITIONS}

For general purpose growth, Escherichia coli MC1061 and B. subtilis PB2 strains were grown in Lysogeny broth (LB). For fluorescence measurements, $B$. subtilis strains were grown in defined liquid medium (M3G; Keijser et al., 2007) buffered at $\mathrm{pH}=5.5$ or 6.4 with $80 \mathrm{mM}$ 2-(N-morpholino)ethanesulfonic acid (MES), or at $\mathrm{pH}=7.0$ or 7.4 with $80 \mathrm{mM} 3$ - $(\mathrm{N}$-morpholino $)$ propanesulfonic acid (MOPS). All cultures were grown at $37^{\circ} \mathrm{C}$, under continuous agitation at $200 \mathrm{rpm}$. When required, the following antibiotics were added: kanamycin for strains carrying pDG148-derived plasmids; $10 \mu \mathrm{g} / \mathrm{ml}$ for $B$. subtilis strains, $50 \mu \mathrm{g} / \mathrm{ml}$ for E. coli strains, spectinomycin for strains carrying pSG1729-derived plasmids or genomic inserts $(50 \mu \mathrm{g} / \mathrm{ml})$. The strains used in this study are listed in Table 1.

\section{SPORULATION OF B. subtilis STRAINS}

Spores of B. subtilis were prepared by glucose depletion of defined liquid medium (M3S, which is M3G without sodium glutamate), at $\mathrm{pH}=7.0$. Cultures were incubated for 4 days at $37^{\circ} \mathrm{C}$ under continuous agitation $(200 \mathrm{rpm})$. Spores were harvested and purified by extensive washing with MilliQ water at $4^{\circ} \mathrm{C}$. The spore crops were inspected by phase-contrast microscopy and were free (>99\%) of vegetative cells, germinating spores, and debris. Spores were stored for up to 1 week in MilliQ water at $4^{\circ} \mathrm{C}$ at optical density $(\mathrm{OD})_{600}=1$.

\section{CLONING OF PROMOTER FUSIONS WITH IpHIuorin}

Our initial experiments suggested that the accuracy of $\mathrm{pH}$ measurements might benefit from increased expression of pHluorin. To improve translation efficiency, the first $24 \mathrm{bp}$ of comGA, with an ATG start codon, were fused to pHluorin by a polymerase chain reaction (PCR) with Pfu polymerase using primers IpHlu_2010_FW and IpHlu_2010_RV. This sequence was subsequently extended with a standard Shine-Dalgarno (SD) region (AAGGAGGAAGCAGGT; Joseph etal., 2001) using primers IpHlu_pDGA_FW. This SD-improved pHluorin (IpHluorin) was

\section{Table 1 | Strains used in this study.}

\begin{tabular}{|c|c|c|}
\hline Strains & Genotype & Reference \\
\hline E. coli MC1061 & Cloning host; $\mathrm{F}^{-}$araD139 (ara-leu)7696 (lac)X74 galU galK hsdR2 mcrA mcrB1 rspL & Casadaban \\
\hline \multicolumn{3}{|l|}{ Bacillus subtilis } \\
\hline PB2 & $\operatorname{trp2C} ; 168$ wild-type & C.W. Price \\
\hline PB2 pDG148 & $\operatorname{trp2C;}$ pDG148 & This work \\
\hline PB2 Pxyl-pHluorin & trp2C; amyE3' spc Pxyl-pHluorin amyE5' & This work \\
\hline PB2 Pxyl-IpHluorin & $\operatorname{trp2C}$; amyE3' spc Pxyl-IpHluorin amyE5' & This work \\
\hline PB2 pDG-pHluorin & $\operatorname{trp2C} ;$ pDG-pHluorin & This work \\
\hline PB2 pDG-IpHluorin & $\operatorname{trp2C;}$ pDG-IpHluorin & This work \\
\hline PB2 PptsG-IpHluorin & trp2C; amyE3' spc PptsG-IpHluorin amyE5' & This work \\
\hline PB2 PspollA-IpHluorin & $\operatorname{trp2C} ;$ amyE3' spc PspollA-IpHluorin amyE5' & This work \\
\hline PB2 PspollID-IpHluorin & trp2C; amyE3' spc PspollID-IpHluorin amyE5' & This work \\
\hline PB2 PsspE-IpHluorin & trp2C; amyE3' spc PsspE-IpHluorin amyE5' & This work \\
\hline
\end{tabular}


inserted between the HindIII and SalI sites of pDG148. This construct, pDG-IpHluorin, was transformed into B. subtilis PB2 and compared with $\mathrm{PB} 2$ carrying pDG-pHluorin to analyze expression levels and $\mathrm{pH}$-dependent characteristics of pHluorin and IpHluorin. Also, a xylose-inducible, genome-integrated expression system was constructed. To this end, IpHluorin was inserted in pSG1729, between the AvrII and HindIII sites, thereby replacing GFP and placing IpHluorin under control of the xylose-inducible $\mathrm{P}_{\mathrm{xyl}}$ promoter.

To monitor the $\mathrm{pH}_{\mathrm{i}}$ of $B$. subtilis for extended periods of time in different phases of its life cycle, without the need for externally supplied expression inducers, the promoter region of several growth phase-specific genes $\left(\mathrm{P}_{\mathrm{ptsG}}\right.$, for vegetative cells growing on glucose, $\mathrm{P}_{\text {spoIIA }}$, specific for pre-septum, sporulating cells, $\mathrm{P}_{\text {sspe }}$, a fore-spore-specific gene, and $\mathrm{P}_{\text {spoIIID }}$, a mother cell-specific promoter) of B. subtilis were selected for their expression levels (Steil et al., 2005; Veening et al., 2006a). Approximately 500 bp upstream of the start codon were selected for cloning. By standardizing the $\mathrm{SD}$ region, we aimed to increase and standardize the expression levels of poorer promoter sites (Ozbudak et al., 2002; Botella et al., 2010). The promoter and SD-IpHluorin sequences were fused by a PCR and inserted in pSG1729, between the AvrII and HindIII sites, thereby replacing the GFP and placing IpHluorin under control of a $B$. subtilis promoter. All enzymes used were obtained from Fermentas (Thermo Fisher Scientific).

Bacillus subtilis PB2 was used as target for our transformations. B. subtilis cells were made transformation-competent as described before (Kunst and Rapoport, 1995). The newly constructed plasmids were integrated in the amyE locus as described (Lewis and Marston, 1999). All plasmids and oligonucleotides used in this study are listed in Tables 2 and 3.

\section{CALIBRATION OF IpHIuOrin}

Bacillus subtilis PB2 containing either pDG148, pDG-pHluorin or pDG-IpHluorin were grown to exponential phase in M3G at $\mathrm{pH} 7.0$ containing $10 \mu \mathrm{g} / \mathrm{ml}$ kanamycin. Bacterial growth and expression levels of ratiometric pHluorin and IpHluorin were monitored in a FluoStar Optima (BMG Labtech, Germany) for $3 \mathrm{~h}$ after addition of $0-1 \mathrm{mM}$ isopropyl $\beta$-D-1-thiogalactopyranoside (IPTG).
For calibration of the $\mathrm{pH}$, expression of ratiometric pHluorin and IpHluorin was induced for $2.5 \mathrm{~h}$ by the addition of $1 \mathrm{mM}$ IPTG. At $\mathrm{OD}_{600}=0.4$ the cells were centrifuged and resuspended in buffers with $\mathrm{pH}$ values ranging from 5.0 to 8.5 prepared from $0.1 \mathrm{M}$ citric acid and $0.2 \mathrm{M} \mathrm{K}_{2} \mathrm{HPO}_{4}$. The intracellular and extracellular $\mathrm{pH}$ were equilibrated by the addition of $1 \mu \mathrm{M}$ valinomycin and $1 \mu \mathrm{M}$ nigericin (Breeuwer et al., 1996). Cells were transferred to black-walled microtiter plates and incubated at $37^{\circ} \mathrm{C}$ in a FluoStar Optima. $\mathrm{OD}_{600}$ was measured before start of the experiment. The ratio of emission intensity at $510 \mathrm{~nm}$ resulting from excitation at 390 and $470 \mathrm{~nm}$ (with photomultiplier gain set to 2,000) was calculated as described previously (Orij et al., 2011). Fluorescence and $\mathrm{OD}_{600}$ were monitored for $30 \mathrm{~min}$, with measurements taken every $5 \mathrm{~min}$. Calibration curves for pHluorin and IpHluorin were identical, with only minor fluctuations in fluorescence in time observed with $\mathrm{pHluorin}$ at $\mathrm{pH}=8.5$. From this, we concluded that the intracellular and extracellular $\mathrm{pH}$ had equilibrated rapidly. B. subtilis PB2 carrying pDG148 was measured for background fluorescence. Background fluorescence was subtracted at individual wavelengths before calculating the ratio. The calibration curve was determined by fitting the data of three independent biological replicates, each consisting of three technical replicates, with a polynomial curve of the third order.

\section{BATCH MEASUREMENTS OF $\mathrm{pH}_{\mathrm{i}}$ DURING SPORULATION, GERMINATION, AND OUTGROWTH}

To monitor $\mathrm{pH}_{\mathrm{i}}$ during growth and sporulation, all B. subtilis strains, wild-type (WT) (PB2) and those with IpHluorin fused to endogenous promoters were grown as described, in M3S without antibiotics, $\mathrm{pH} 7.0$, to an $\mathrm{OD}_{600}=0.1$ in an incubator at $37^{\circ} \mathrm{C}$ under continuous agitation $(200 \mathrm{rpm})$. Cell suspensions were diluted twofold by adding $50 \mu \mathrm{l}$ of culture to $50 \mu \mathrm{l}$ of medium in black microtiter plates which were then monitored in a FluoroStar Optima BMG (Labtech, Germany) at $37^{\circ} \mathrm{C} . \mathrm{OD}_{600}$ and $\mathrm{pH}$ measurements were taken every $10 \mathrm{~min}$ for $48 \mathrm{~h}$. The plates were shaken $(200 \mathrm{rpm})$ in between measurements thus ensuring optimal growth (Ter Beek, 2009). For spore germination, washed spores were heat activated $\left(30 \mathrm{~min}, 70^{\circ} \mathrm{C}\right.$, then cooled on ice) and subsequently mixed 1:1 with $2 \times$ concentrated $\mathrm{M} 3$ with or without glucose, containing weak organic acid (WOA) in predetermined

Table 2 | Plasmids used in this study.

\begin{tabular}{|c|c|c|}
\hline Plasmid & Genotype & Reference or construction \\
\hline pDG148 & bla ble kan lacl Pspac & Stragier et al. (1988) \\
\hline pDG-pHluorin & (pDG148); pHluorin & \\
\hline pDG-IpHluorin & (pDG148); IpHluorin & This work \\
\hline pSG1729 & bla amyE3' spc Pxyl-gfpmut1' amyE5' & Lewis and Marston (1999) \\
\hline pSG-pHluorin & bla amyE3' spc Pxyl-pHluorin amyE5' & This work \\
\hline pSG-IpHluorin & bla amyE3' spc Pxyl-IpHluorin amyE5' & This work \\
\hline 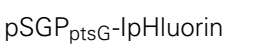 & bla amyE3' spc PptsG-IpHluorin amyE5' & This work \\
\hline pSGP spollA-IpHluorin $_{1}$ & bla amyE3' spc PspollA-lpHluorin amyE5' & This work \\
\hline $\mathrm{pSGP}_{\text {spollID-IpHluorin }}$ & bla amyE3' spc PspollID-IpHluorin amyE5' & This work \\
\hline pSGP sspE-IpHluorin & bla amyE3' spc PsspE-IpHluorin amyE5' & This work \\
\hline
\end{tabular}


Table 3 | Oligonucleotides used in this study.

\begin{tabular}{|c|c|c|}
\hline IpHlu2010_FW & ATGGATTCAATAGAAAAGGTAAGCATGAGTAAAGGAGAAGAAC & Forward primer for IpHluorin \\
\hline IpHlu148A_FW & CCCAAGCTTAAGGAGGAAGCAGGTATGGATTCAATAGAAAAG & Forward IpHluorin primer for pDG148 \\
\hline IpHlu1729A_FW & ACGCCCTAGGATGGATTCAATAGAAAAGGTAAGC & Forward IpHluorin primer for pSG1729 \\
\hline PptsG_IpHlu_RV & CATACCTGCTT CСTCCTTTTTTACTAGTCTGACCTTAC & $3^{\prime}$ end of $P_{p t s G}$ \\
\hline PptsG_IpHlu_FW & GTAAGGTCAGACTAGTAAAAAAGGAGGAAGCAGGTATG & $3^{\prime}$ of $P_{p t s G}$ and $5^{\prime}$ of $/ p H$ luorin \\
\hline PspollAA_FW & ACGCCCTAGGCCATAGCGGTTGTATTC & $5^{\prime}$ end of $P_{\text {spollA }}$ \\
\hline PspollAA_IpHlu_RV & CATACCTGCTTCCTCCTTGATATGATCGGATAATGAGTGTTTC & $3^{\prime}$ end of $P_{\text {spollA }}$ \\
\hline PspollID_IpHlu_FW & СTCATTTCACACTTCTCACATCCATTTTAAGGAGGAAGCAGGTATG & $3^{\prime}$ of $P_{p t s G}$ and $5^{\prime}$ of IpHluorin \\
\hline PsspE_FW & ACGCCCTAGGTGAACATTAATGCGAAAGCATTG & $5^{\prime}$ end of $P_{S S P E}$ \\
\hline PsspE_IpHlu_RV & СATACCTGCTTCCTCCTTCGGTCATTAGAATGTCCAG & $3^{\prime}$ end of $P_{S S P E}$ \\
\hline PsspE_IpHlu_FW & CTGGACATTCTAATGACCGAAGGAGGAAGCAGGTATG & $3^{\prime}$ of $P_{S S P E}$ and $5^{\prime}$ of IpHluorin \\
\hline
\end{tabular}

Underlined bases: restriction enzyme recognition sites; bases in italics: Shine-Dalgarno sequence; bold bases: start codon.

concentrations. To trigger germination, $5 \mu \mathrm{l} 20 \times$ concentrated AGFK (10 mM L-asparagine, $10 \mathrm{mM}$ D-glucose, $1 \mathrm{mM}$ D-fructose, $1 \mathrm{mM} \mathrm{KCl}$; Wax and Freese, 1968) was added. Microtiter plates were placed in a FluoStar Optima (BMG Labtech, Germany) at $37^{\circ} \mathrm{C}$ and shaken between measurements (200 rpm). Growth was monitored for 2-12 h, with $\mathrm{pH}$ and $\mathrm{OD}_{600}$ measurements taken every $10 \mathrm{~min}$.

\section{MICROSCOPY}

To verify if expression of IpHluorin was correctly localized, B. subtilis cells were cultured as described above for batch measurements at $\mathrm{pH}=7.0$. All strains were grown as described to exponential phase or for 16-24 h to observe sporulating cells. Cells were immobilized on 1\% agarose (Koppelman et al., 2004), and photographed with a CoolSnap $f x$ (Photometrics) charge-coupled device (CCD) camera mounted on an Olympus BX-60 fluorescence microscope through an UPLANFI $100 \times / 1.3$ oil objective (Japan) with a 41017 - Endow GFP/EGFP Bandpass filter (Chroma Technology Corp., Bellows Falls, VT, USA).

\section{RESULTS}

\section{IMPROVED EXPRESSION OF pHluorin}

Many microorganisms have an internal (cytosolic and/or mitochondrial) $\mathrm{pH}$ between 7 and 8 (Orij et al., 2009; Slonczewski et al., 2009) during optimal growth and maintaining $\mathrm{pH}$ homeostasis is of vital importance for most, including B. subtilis where $\mathrm{pH}_{\mathrm{i}}$ differences have been inferred for its various developmental phases. We now used the $\mathrm{pH}$-sensitive GFP pHluorin, developed for yeast (Miesenböck et al., 1998), to directly measure on-line the $\mathrm{pH}_{\mathrm{i}}$ dynamics in $B$. subtilis. Codon usage of this GFP was not optimized for B. subtilis and our initial experiments suggested that expression might be improved. It was shown previously that addition of the first eight amino acids of com $G A$ improved translation initiation efficiency of CFP and YFP in B. subtilis (Veening et al., 2004). We used this approach to construct improved pHluorin (IpHluorin; Figure 1A).

To analyze fluorescence intensity of Bacillus cells harboring pDG148, pDG-pHluorin, or pDG-IpHluorin cells were transferred to microtiter plates containing $0-1 \mathrm{mM}$ IPTG to induce expression. Cell growth was monitored for $3 \mathrm{~h}$, together with fluorescence emission at $510 \mathrm{~nm}$ upon excitation at 390 and $470 \mathrm{~nm}$. The three strains compared had identical growth rates (not shown). Fluorescence intensity after $2.5 \mathrm{~h}$ is shown in Figure 1B, and depended on the concentration of IPTG. Cells expressing IpHluorin had the highest signal intensity at $1 \mathrm{mM}$ IPTG, approximately 40\% higher than pHluorin under the same conditions. The most important characteristic of pHluorin is its shift in excitation wavelength depending on the $\mathrm{pH}$ of its surroundings. To establish if the addition of eight amino acids at the $\mathrm{N}$-terminus would alter these characteristics, calibration curves for pHluorin and IpHluorin were made (Figure 1C for IpHluorin, not shown for pHluorin). Both growth rate and the ratiometric characteristics were similar and allowed reliable $\mathrm{pH}_{\mathrm{i}}$ readings in a range between $\mathrm{pH} 5$ and 8.5 in live $B$. subtilis cultures.

\section{THE INTERNAL pH VARIES WITH GROWTH PHASE}

The cytosolic $\mathrm{pH}$ is a crucial parameter for bacteria because it modulates the activity of many enzymes (Vojinovic and Von Stockar, 2009) and in many species plays a crucial role in generating the 


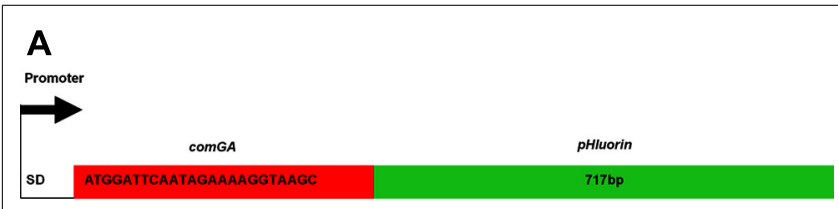

B

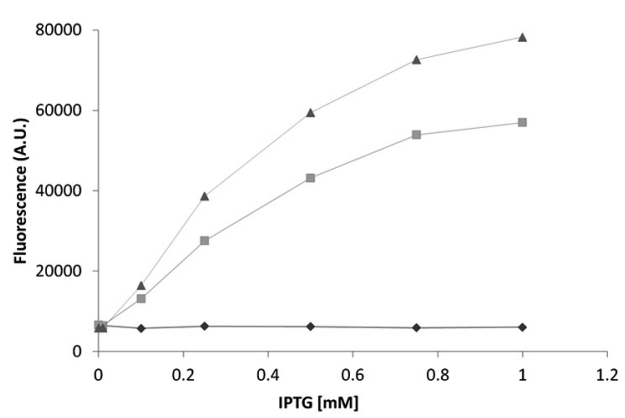

C

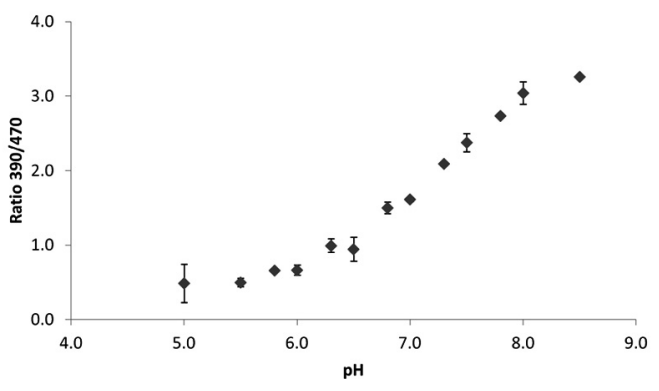

FIGURE 1 | Improved expression of pHluorin in B. subtilis.

(A) Schematic overview of the improved pHluorin construct. SD Shine-Dalgarno sequence. comGA - the first 24 bp of comGA, with the start codon converted to ATG. (B) Expression levels of pHluorin and improved pHluorin after induction with IPTG. Fluorescence (AU, arbitrary units) at $510 \mathrm{~nm}$ from excitation at $390 \mathrm{~nm}$ was measured after $2.5 \mathrm{~h}$ of induction and normalized to $\mathrm{OD}_{600}$. Diamonds, control (pDG148); squares, pHluorin (pDG-pHluorin); triangles, IpHluorin (pDG-IpHluorin). (C) Calibration curve for IpHluorin. Error bars indicate standard deviations $(n=3)$.

proton-motive force (Shioi et al., 1980; Slonczewski et al., 2009). To monitor $\mathrm{pH}_{\mathrm{i}}$ during various stages of growth in Bacillus, we fused promoters of strongly expressed, growth phase-specific genes to IpHluorin. This allowed us to measure $\mathrm{pH}_{\mathrm{i}}$ of $B$. subtilis without addition of inducers such as IPTG or xylose (Figures 2A-H). The selected promoters and their specific expression phase are shown in Table 4.

To monitor the $\mathrm{pH}_{\mathrm{i}}$ during growth in minimal medium with glucose as the only carbon source, we used the promoter of $p t s G$, which encodes the glucose-specific enzyme II of the carbohydrate:phosphotransferase system to drive IpHluorin expression. $\mathrm{P}_{\mathrm{ptsG}}$ is a strong promoter during vegetative growth on glucose (Botella et al., 2010). Expression of IpHluorin from the $\mathrm{P}_{\mathrm{pts}}$ promoter follows the growth curve closely (Figure 3A). When the cells die or move into stationary phase (after $7.5 \mathrm{~h}$ ), the signal intensity remains high and stable. The sporulation-specific promoters (Figure 4B) are activated after the drop in $\mathrm{OD}_{600}$, signifying the onset of sporulation.

The $\mathrm{pH}_{\mathrm{i}}$ of $B$. subtilis reaches its highest value of around 8 during exponential growth. This value is in agreement with earlier
Table 4 | Promoters used for IpHluorin expression.

\begin{tabular}{lll}
\hline Promoter & Regulator & Corresponding growth phase \\
\hline$P_{\text {ptsG }}$ & $\sigma^{A}$ & Growth on glucose (Botella et al., 2010) \\
$P_{\text {spollA }}$ & Spo0A, $\sigma^{F, G, H}$ & Early sporulation Mang et al., 2006) \\
$P_{\text {spollID }}$ & $\sigma^{E}$ & Early sporulation, mother cell-specific \\
& & Wang et al., 2006) \\
$P_{\text {SSpE }}$ & $\sigma^{G}$ & Late sporulation, spore-specific \\
& & Wang et al., 2006)
\end{tabular}

reported values ranging from $\mathrm{pH}=7.8$ to 8.1 (Setlow and Setlow, 1980; Magill et al., 1994). At the drop in $\mathrm{OD}_{600}$, cells either die or differentiate and initiate sporulation or remain in stationary phase. This was accompanied by an apparent steep decrease in $\mathrm{pH}_{\mathrm{i}}$, to 7.0 in vegetative cells expressing IpHluorin from $\mathrm{P}_{\mathrm{ptsG}}$. Likely, this at least partially is indicative for cell lysis as a strong fluorescent signal could also be detected in the medium after spinning down the cells. Additionally, it is possible that morphological changes of the cell affect their optical properties. Sporulating cells are, for instance, smaller than exponentially growing cells. Hence, after sporulation commences, the $\mathrm{pH}$ values observed with $\mathrm{P}_{\mathrm{ptsG}}{ }^{-}$ IpHluorin can no longer be considered an accurate estimate of the intracellular $\mathrm{pH}$ in vegetative cells. Apart from aberrant values due to cell lysis, the $\mathrm{P}_{\mathrm{ptsG}}$-driven IpHluorin may also get trapped in sporulating cells so that the observed $\mathrm{pH}$ from $\mathrm{P}_{\mathrm{ptsG}}$-driven IpHluorin is the average of sporulating and non-sporulating cells as well as the medium. Subsequently, the $\mathrm{OD}_{600}$ rose again slowly and the apparent $\mathrm{pH}$ increased to 7.4 (Figure 3). We do not know from which cells this signal originates as it may represent the average of various differentiation types, all expressing IpHluorin. To deconvolute these signals, single cell measurements are needed.

\section{SPORULATION-SPECIFIC EXPRESSION OF IpHluorin}

Sporulation of B. subtilis is a well-described, carefully orchestrated process where a number of different sigma factors are activated during subsequent stages (Wang et al., 2006). It has been reported that the $\mathrm{pH}_{\mathrm{i}}$ of Bacillus spores is lower than that of vegetative cells (Magill et al., 1994). We set out to measure the $\mathrm{pH}$ in spores and at what stage in sporulation the drop in $\mathrm{pH}$ starts and when the $\mathrm{pH}$ would rise again during germination. For this purpose, we constructed strains with early and late (pre)spore-specific expression of IpHluorin. We selected promoters that would be active in the pre-spore and mother cell at different times during sporulation to monitor $\mathrm{pH}_{\mathrm{i}}$ of both cells separately. Expression from $\mathrm{P}_{\text {spoIIA, }}$ $\mathrm{P}_{\text {spoIIID, }}$ and $\mathrm{P}_{\text {sspe }}$ starts after the drop in $\mathrm{OD}_{600}$. The surviving cells may prepare for diauxic growth or sporulation (Veening et al., 2008). This characteristic allowed us to measure differences in $\mathrm{pH}_{\mathrm{i}}$ in both mother cell and pre-spore in the subpopulation that initiates sporulation. Expression levels from $\mathrm{P}_{\text {spoIIA }}, \mathrm{P}_{\text {spoIIID }}$, and $\mathrm{P}_{\text {sspE }}$ are lower than of $\mathrm{P}_{\mathrm{ptsG}}$, but are still reliable and strong enough to allow $\mathrm{pH}$ monitoring (Figures 3A,B). For the sporulation-specific promoters, a cut-off of 1,000 arbitrary units in the 390 to $510 \mathrm{~nm}$ fluorescence channel was used for $\mathrm{pH}_{\mathrm{i}}$ calculations. 


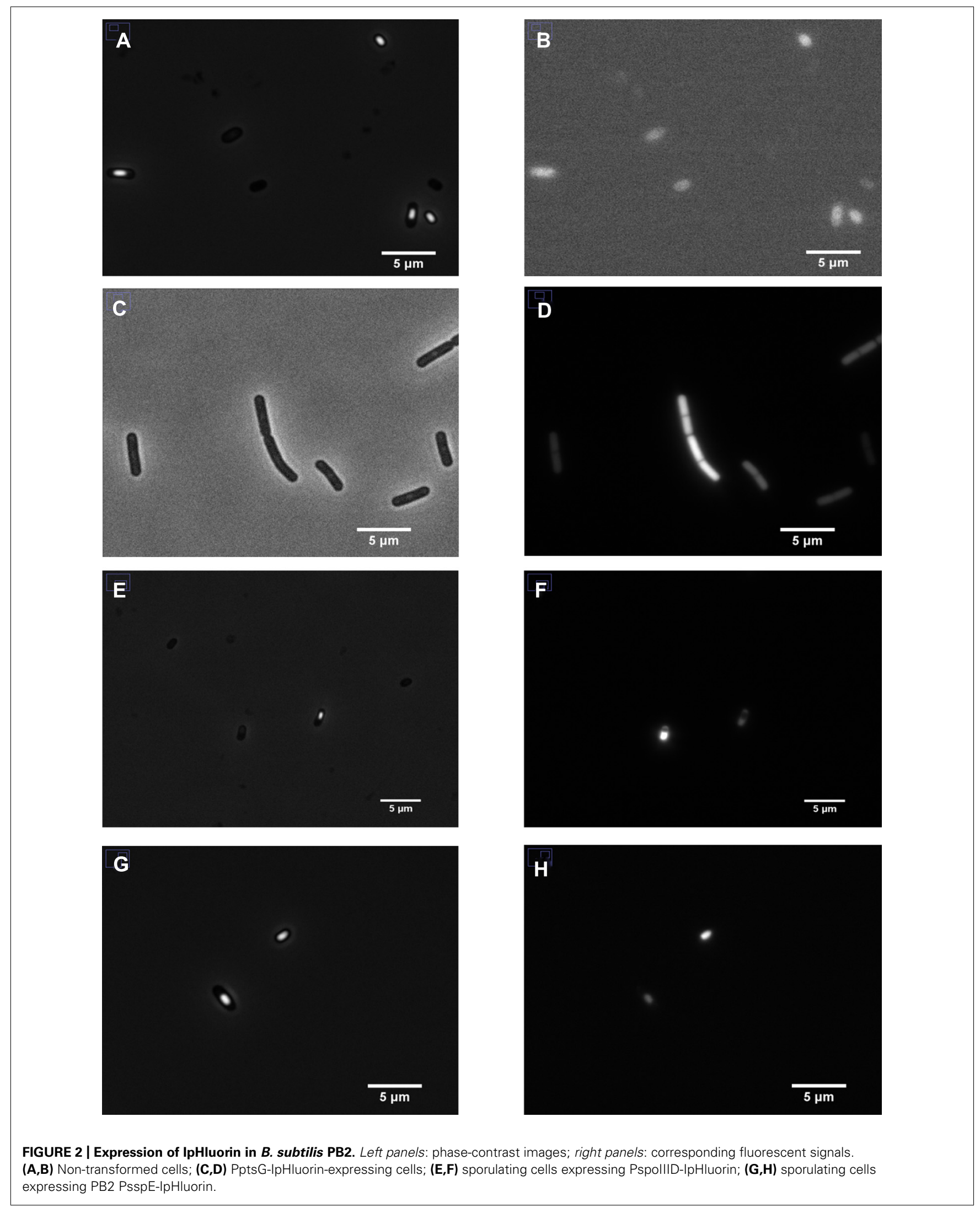




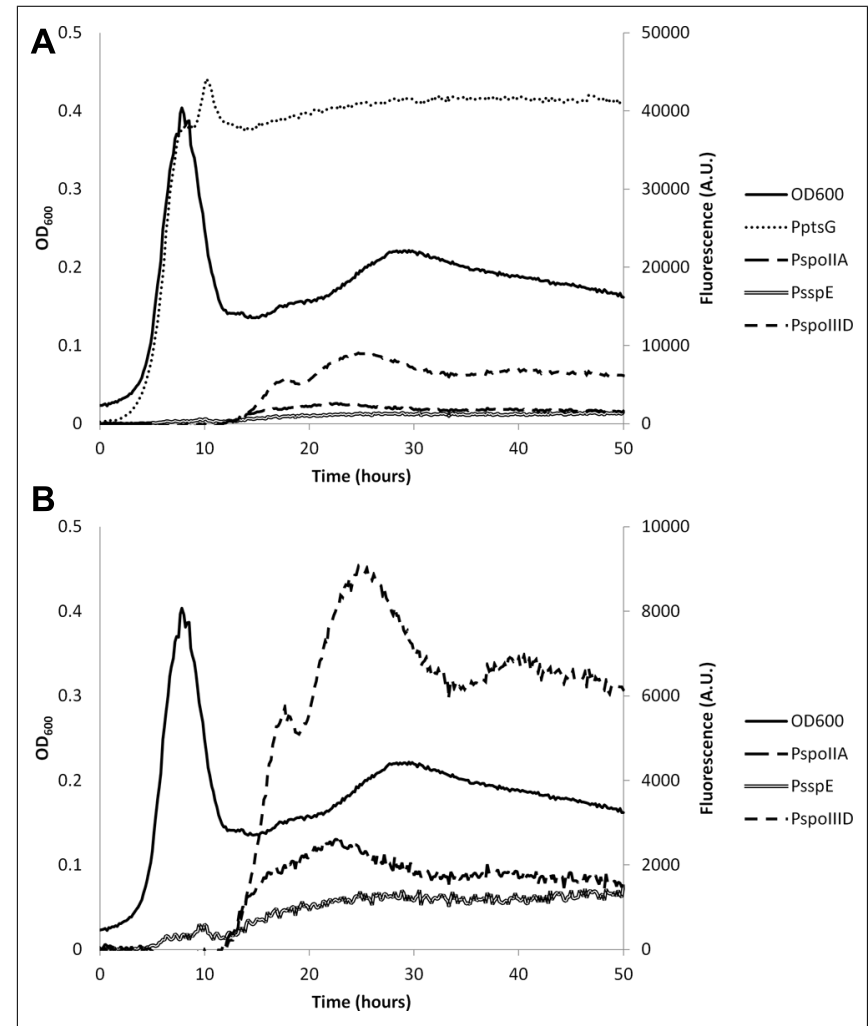

FIGURE 3 | Representative example of the expression levels of IpHluorin from different promoters during different growth stages.

(A) Fluorescence levels from excitation at $390 \mathrm{~nm}$ and emission at $510 \mathrm{~nm}$ from different promoters used. (B) Identical to (A), but without

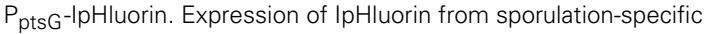
promoters starts only after the drop in $\mathrm{OD}_{600}$

SpoIIA is activated by high levels of activated Spo0A and its presence was shown to be a reliable indicator for cells that initiate sporulation (Veening et al., 2005). Indeed, a fluorescent signal of a GFP reporter under control of the SpoIIA promoter can be found in both mother cell and fore-spore (our unpublished observations; Veening et al., 2006b). Expression of genes in the mother cell regulated by $\mathrm{P}_{\text {spoIIID }}$ follows that of those regulated by $\mathrm{P}_{\text {spoIIA, }}$, as expected, but because expression levels of $\mathrm{P}_{\text {spoIIID-controlled }}$ IpHluorin are higher, reliable $\mathrm{pH}_{\mathrm{i}}$ measurements can be obtained earlier with the latter. Initially, the sporulating subpopulation had a $\mathrm{pH}_{\mathrm{i}}$ that closely resembled the $\mathrm{pH}_{\mathrm{i}}$ of exponentially growing cells measured with the $\mathrm{P}_{\mathrm{pts}}$-IpHluorin strain. The mother cell ( $\mathrm{P}_{\text {spoIIID-IpHluorin }}$ ) had a $\mathrm{pH}$ of 7.8 after $17 \mathrm{~h}$ of incubation. IpHluorin expressed from the spore-specific promoter $\mathrm{P}_{\mathrm{sspE}}$ revealed $\mathrm{pH}$ values of 7.4. The mother cell-specific expression of IpHluorin from the spoIIID promoter decreased after $25 \mathrm{~h}$ of culture. At that time point and from then onward, an apparent decrease measured with the mother cell-specific promoter driving IpHluorin expression was observed. This data, however, may at least partially be influenced by mother cell lysis and release of IpHluorin into the medium. The inferred $\mathrm{pH}$ at $40 \mathrm{~h}$ of culture closely resembled medium $\mathrm{pH}$, corroborating this notion.

The decrease in $\mathrm{pH}_{\mathrm{i}}$ in the fore-spore $\left(\mathrm{P}_{\mathrm{sspE}}\right.$-IpHluorin) drops below the medium $\mathrm{pH}$ and its fluorescent signal can clearly be

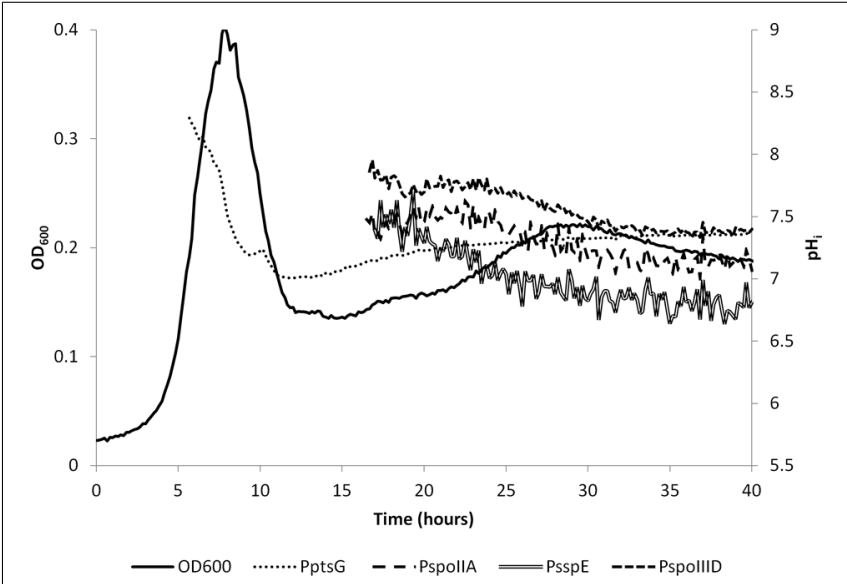

FIGURE 4 | Internal pH as measured with IpHluorin expressed from different promoters. The $\mathrm{pH}$ is calculated from when the $390 \mathrm{~nm}$ channel exceeded 1,000 units. $\mathrm{pH}$ from the spore-specific promoters is calculated from approximately $17 \mathrm{~h}$ onward. Lines represent actual data from a representative example.

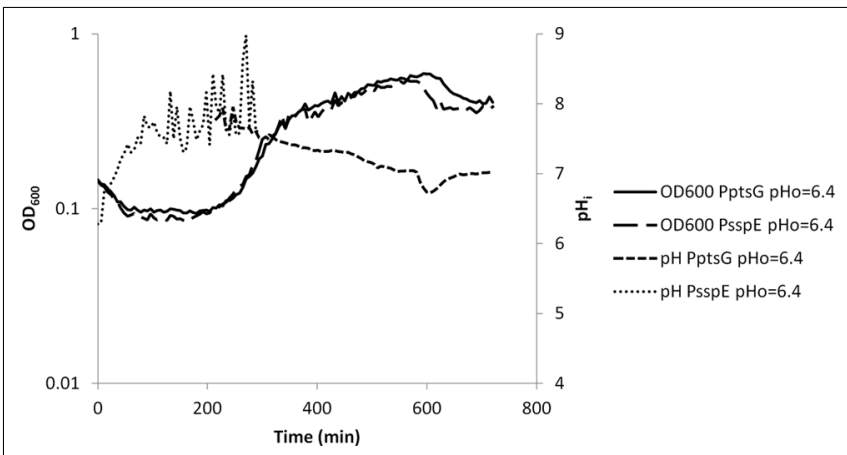

FIGURE 5 | Internal pH during spore germination and outgrowth. IpHluorin accumulated in the spores (from expression controlled by $\mathrm{P}_{\mathrm{SspE}}$ ) allows $\mathrm{pH}$ measurements from $t=0$ to approximately $300 \mathrm{~min}$. Expression of IpHluorin from $\mathrm{P}_{\mathrm{ptsG}}$ allows calculation of the $\mathrm{pHi}$ from approximately $200 \mathrm{~min}$. Data are from a representative example of germination and outgrowth of $B$. subtilis spores at an external $\mathrm{pH}$ of 6.4 .

observed inside maturing spores (Figure $2 \mathbf{H}$ ). Noticeably, spores have a very low water activity and optical properties dissimilar from vegetative cells, which may obscure the $\mathrm{pH}$ as defined as the number of free protons (Sunde et al., 2009).

Our data indicates that at $17.5 \mathrm{~h}$ of culture, the $\mathrm{pH}_{\mathrm{i}}$ of the fore-spore is 7.4, as reported by $\mathrm{P}_{\mathrm{sspE}}$-IpHluorin. After $40 \mathrm{~h}$, the $\mathrm{pH}$ value of 6.8 reported by $\mathrm{P}_{\mathrm{sspE}}$-IpHluorin is approaching the reported value for Bacillus spores $\left(\mathrm{pH}_{\mathrm{i}}=6.0 \pm 0.3\right.$; Barton et al., 1980; Setlow and Setlow, 1980; Magill et al., 1994, 1996). Likely, because at this time point the population is still a mix of some forespore-containing cells as well as many free spores, the observed $\mathrm{pH}$ is slightly higher than the reported values for isolated Bacillus spores. Corroborating this, when we washed and isolated the spores our pHluorin-based measurement of the $\mathrm{pH}_{\mathrm{i}}$ of $B$. subtilis spores also indicated values around $6.0 \pm 0.3$ (see, e.g., pHi data of time point 0 obtained with IpHluorin driven by $\mathrm{P}_{\text {sspe }}$ in Figure 5 and beyond). 


\section{INTERNAL pH DURING SPORE GERMINATION AND OUTGROWTH}

As described above, IpHluorin expressed from $\mathrm{P}_{\text {sspE }}$ accumulates in mature spores. Germination and outgrowth were monitored used B. subtilis $\mathrm{PB} 2 \mathrm{P}_{\mathrm{sspE}}$-IpHluorin and B. subtilis $\mathrm{PB} 2 \mathrm{P}_{\mathrm{ptsG}^{-}}$ IpHluorin. When germination is triggered by addition of a mixture of asparagine, glucose, fructose and potassium (AGFK), the $\mathrm{OD}_{600}$ of the spore crop drops, because the refractile spores turn phasedark, due to water uptake. Simultaneously, the spore's $\mathrm{pH}_{\mathrm{i}}$ rises. Depending on the medium $\mathrm{pH}$, the $\mathrm{pH}_{\mathrm{i}}$ rises to 7.0-7.4 (Figure 5 and our unpublished observations for germination at $\mathrm{pH} 7.4$, respectively). In the case of germination at $\mathrm{pH}=6.4$, this indicates the establishment of a $\mathrm{pH}$ gradient. Not all spores germinate at the same time, and significant heterogeneity can be observed in the timing of germination and outgrowth (Smelt et al., 2008). Since this is a mixed population, consisting of phase-bright and germinating spores, the actual $\mathrm{pH}$ change in individual germinating spores may differ.

During the lag phase between germination and outgrowth, the $p t s G$ promoter is activated. Parallel expression of IpHluorin from this promoter shows that the $\mathrm{pH}$ measured this way lies between 7.5 and 7.8. This range of $\mathrm{pH}$ values is maintained during exponential growth. A generally observed slow decrease in $\mathrm{pH}$ may be due to acidification of the medium by acetic acid or $\mathrm{CO}_{2}$ (Russell and Diez-Gonzalez, 1998; Orij, 2010). After approximately $600 \mathrm{~min}$, there is a sudden drop in $\mathrm{pH}$ and $\mathrm{OD}_{600}$ as described above (Figure 5).

Germination with medium $\mathrm{pH}=7.4$ shows a more rapid decrease in $\mathrm{OD}_{600}$ and an equally faster rise in $\mathrm{pH}_{\mathrm{i}}$. Also, when outgrowth commences, $\mathrm{pH}_{\mathrm{i}}$ of these cells is higher, but follows a similar trend as with medium at $\mathrm{pH}=6.4$.

\section{INTERNAL pH DURING SPORE GERMINATION WITH WEAK ACID STRESS}

Dormant spores are highly resistant to antimicrobial treatment, but also metabolically inert (Brul and Coote, 1999). When germination is triggered, the spore becomes more sensitive. Also, it has been observed that germination of Bacillus spores can be inhibited by various preservatives (Cortezzo et al., 2004; Van Melis et al., 2011). When spores start to germinate, they release protons and the $\mathrm{pH}_{\mathrm{i}}$ rises. Also, during this stage water is taken up and metabolism should be restarted. These processes might be a target moment for WOAs to halt outgrowth of the germinating spore.

Acetic and sorbic acid are amongst the most commonly used food preservatives (Stratford et al., 2009; Ter Beek and Brul, 2010; Ullah et al., 2012). While both WOAs have a similar $\mathrm{p} K_{\mathrm{a}}$ value, sorbic acid is clearly the more potent antimicrobial compound. We compared the effects of sorbic and acetic acid on germination and outgrowth by using concentrations of both acids that had a similar effect on growth rate (Ter Beek, 2009). Low concentrations of both acids reduced the exponential growth rate by approximately $50 \%$. Spores germinating in medium $(\mathrm{pH}=6.4)$ with $3 \mathrm{mM}$ K-sorbate had a decreased rate of $\mathrm{pH}_{\mathrm{i}}$ increase. In controls the $\mathrm{pH}_{\mathrm{i}}$ increase between the start of germination and $t=90 \mathrm{~min}$ was 1.4 units whilst with $3 \mathrm{mM} \mathrm{K}$-sorbate this was 0.7 units. At the onset of the exponential phase, the $\mathrm{pH}_{\mathrm{i}}$ which gradually decreased from $\mathrm{pH}=7.4$ to 7.2 at $t=11 \mathrm{~h}$ (Figure 6A). Twenty-five millimolars of $\mathrm{K}$-acetate allowed a rapid increase in $\mathrm{pH}_{\mathrm{i}}$ during germination.
The $\mathrm{pH}_{\mathrm{i}}$ during exponential growth remained stable at 7.2 during the experiment (Figure 7A).

High concentrations of WOAs were selected to reduce growth

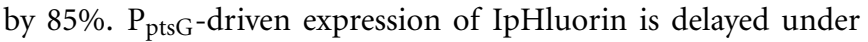
these conditions, while spore-specific IpHluorin can be observed for longer periods of time because the signal is not diluted out. $\mathrm{K}$-sorbate $(10 \mathrm{mM})$ is shown to delay the maximum drop in $\mathrm{OD}_{600}$ indicative for spore germination. The data in Figure 6B show a drop from $\mathrm{OD}_{600} 0.13$ to 0.08 in 216 min rather than from 0.13 to 0.07 in $84 \mathrm{~min}$ as was seen in the control shown in Figure 5. The rise of the $\mathrm{pH}_{\mathrm{i}}$ was here similarly delayed as was the case with $3 \mathrm{mM}$ K-sorbate. Such effects were not seen with $80 \mathrm{mM} \mathrm{K}$-acetate, although the reduction in growth rate is similar (Figure 7B).

To further confirm the observation that sorbic acid inhibited the development of a positive inside $\mathrm{pH}$ gradient, spores of $B$. subtilis $\mathrm{PB} 2 \mathrm{P}_{\mathrm{sspE}}$-IpHluorin were incubated with identical concentrations of either sorbic or acetic acid in medium without glucose other than present as germinant. When germination was triggered by addition of AGFK, spores incubated with sorbic acid showed a clear concentration dependant reduction in $\mathrm{OD}_{600}$ droprate as well as a reduced $\mathrm{pH}_{\mathrm{i}}$ increase-rate. The OD drop-rate decreased from $80 \times 10^{-3}$ to $40 \times 10^{-3} \mathrm{OD}_{600} / \mathrm{min}$ when $0.5 \mathrm{mM}$ undissociated sorbic acid was present (Figure $\mathbf{8 B}$ ). Such effects were not seen with acetic acid at identical concentrations, which

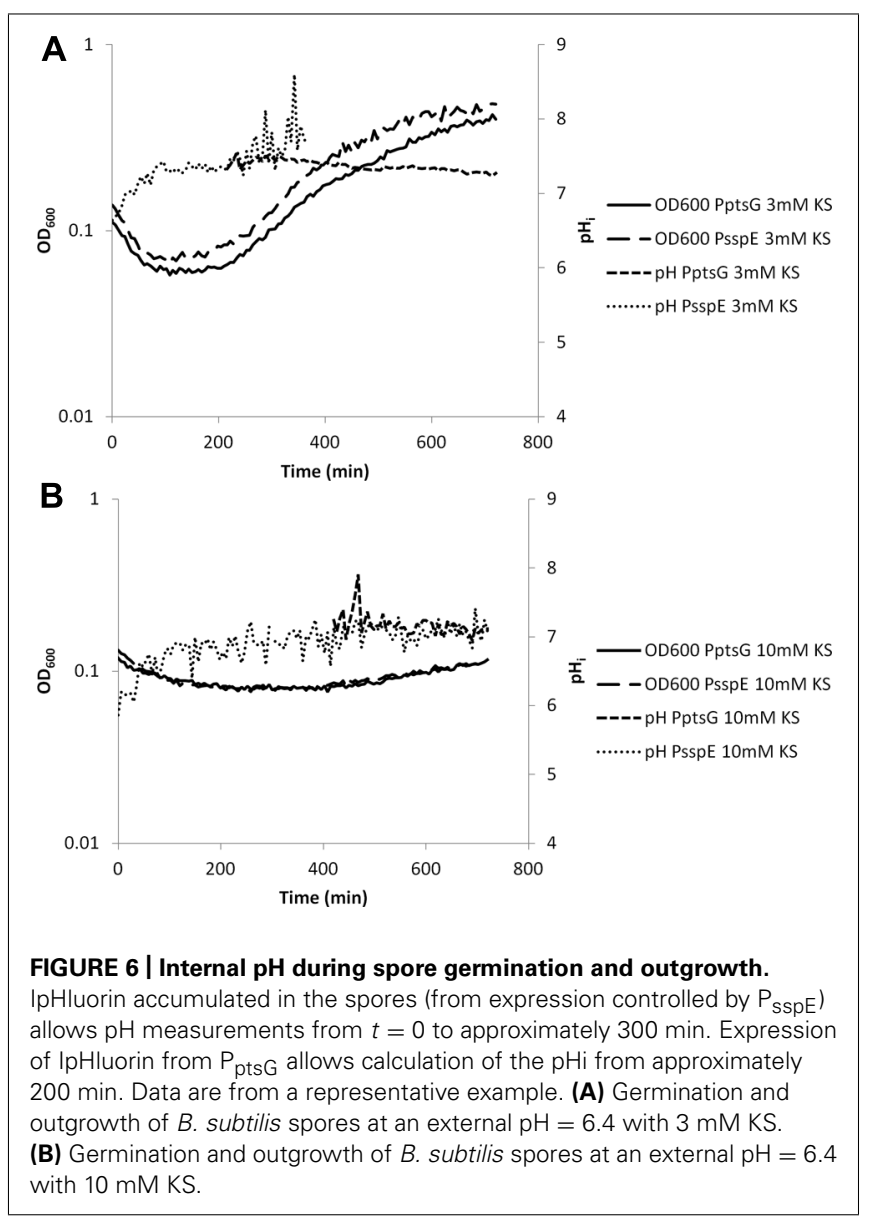




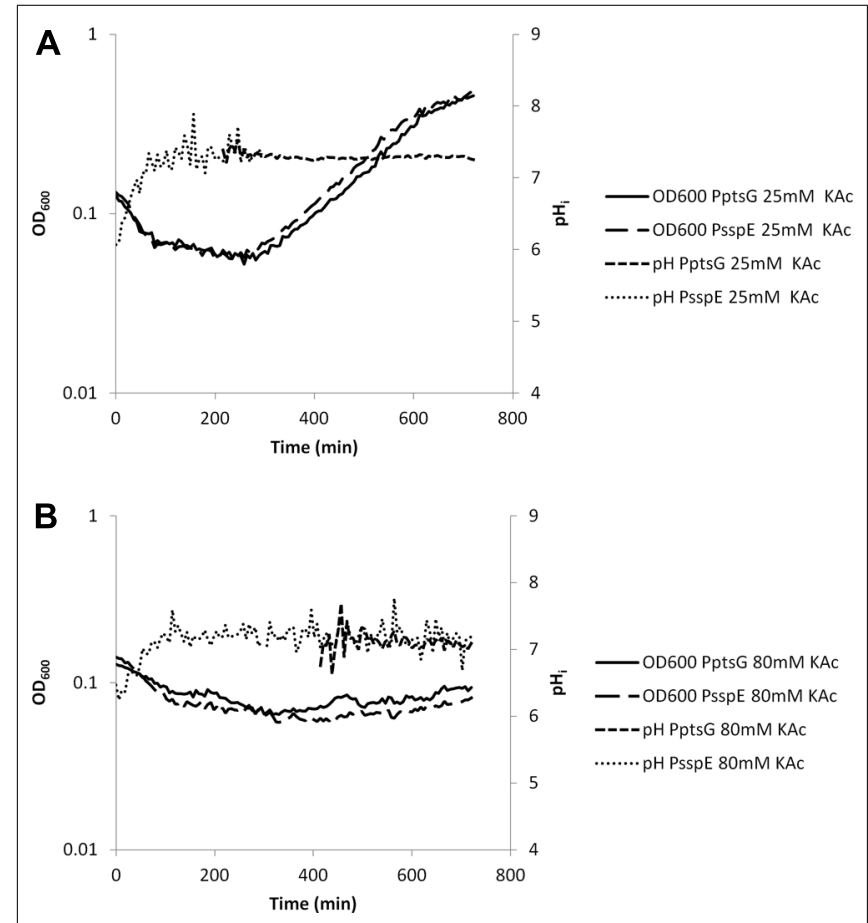

FIGURE 7 | Internal pH during spore germination and outgrowth. IpHluorin accumulated in the spores (from expression controlled by $\mathrm{P}_{\mathrm{ssp}}$ ) allows $\mathrm{pH}$ measurements from $t=0$ to approximately $300 \mathrm{~min}$. Expression of IpHluorin from $\mathrm{P}_{\mathrm{ptsG}}$ allows calculation of the $\mathrm{pHi}$ from approximately $200 \mathrm{~min}$. Data are from a representative example. (A) Germination and outgrowth of $B$. subtilis spores at an external $\mathrm{pH}=6.4$ with $25 \mathrm{mM} \mathrm{KAc}$. (B) Germination and outgrowth of $B$. subtilis spores at an external $\mathrm{pH}=6.4$ with $80 \mathrm{mM} \mathrm{KAc}$.

behaved virtually identical to non-stressed germinating spores (Figures 8A,C). These observations are in agreement with earlier reports stating that sorbic acid can specifically inhibit germination of $B$. cereus and $B$. subtilis, likely by interacting with germinant receptors (Cortezzo et al., 2004; Van Melis et al., 2011).

\section{DISCUSSION}

We show here that IpHluorin is an accurate, versatile probe to investigate the $\mathrm{pH}_{\mathrm{i}}$ of $B$. subtilis. We were able to improve expression of pHluorin by fusion of the first $24 \mathrm{bp}$ of comGA with the pHluorin-encoding gene. Genomic integration of IpHluorin resulted in more homogeneous expression levels compared to a multi-copy plasmid. It also resulted in a more stable construct, not requiring antibiotics for maintenance of the IpHluorin gene during extended periods of growth (not shown). The use of genomically integrated constructs with endogenous promoters for the expression of IpHluorin resulted in a strong enough signal for accurate $\mathrm{pH}$ measurements during exponential growth on glucose as well as compartment-specific $\mathrm{pH}_{\mathrm{i}}$ measurements during sporulation. The IpHluorin that accumulates in the spore under control of $\mathrm{P}_{\mathrm{sspE}}$ allows $\mathrm{pH}_{\mathrm{i}}$ measurements of the B. subtilis spore. During spore germination and outgrowth, the signal from IpHluorin, expressed from $\mathrm{P}_{\text {sspE }}$ overlaps slightly in time with $\mathrm{P}_{\text {ptsG }}$-IpHluorin expression, thus allowing continuous $\mathrm{pH}_{\mathrm{i}}$ monitoring during germination and outgrowth in

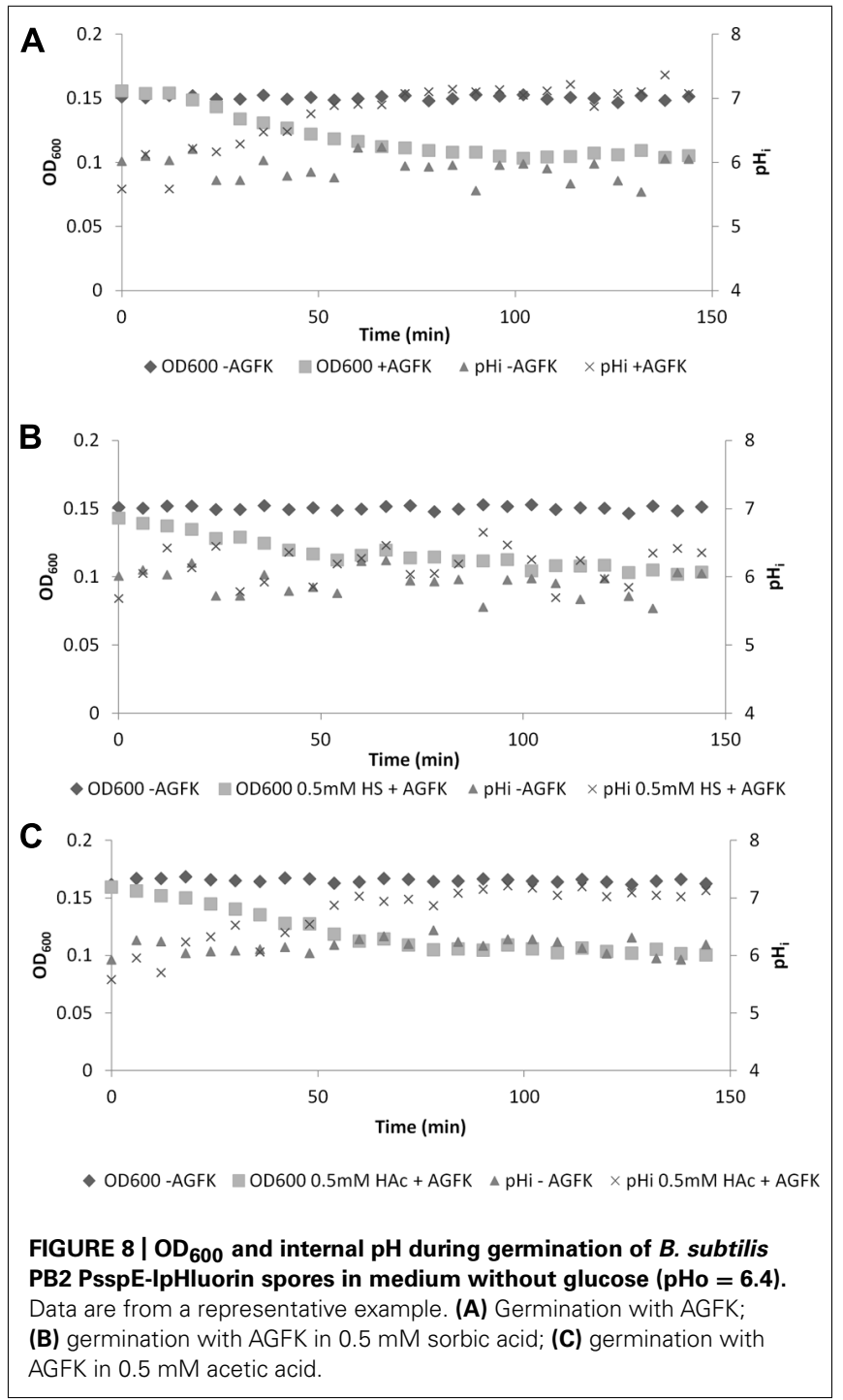

batch. The $\mathrm{pH}$ values we have observed here closely resemble those found with other methods. During exponential growth, the $\mathrm{pH}_{\mathrm{i}}$ approaches $\mathrm{pH}=8$. The $\mathrm{pH}_{\mathrm{i}}$ of $B$. subtilis spores was also found to lie at approximately $\mathrm{pH}=6$. Despite the fact that expression levels of IpHluorin are much lower in spores, the $\mathrm{pH}$ value observed again closely corresponds to earlier reported values. The notion that during outgrowth a $\mathrm{pH}$ is observed that closely resembles the $\mathrm{pH}_{\mathrm{i}}$ during exponential growth (as observed with $\mathrm{P}_{\mathrm{ptsG}}$-IpHluorin) further corroborates the accuracy of our method.

Other methods to measure $\mathrm{pH}_{\mathrm{i}}$ generally involve compounds that are hydrophobic and have WOA groups and may act as uncouplers, thereby depleting the $\Delta \mathrm{pH}$ and influencing $\Delta \Psi$ over the membrane. They are also more labor-intensive when high temporal resolution is required and except for fluorescent dyes do not allow cell type-specific pH measurements. However, these methods require long-term incubation with the dye plus extensive washing, taking up to $20 \mathrm{~min}$ to prepare the sample. Future studies will have to determine the phototoxicity and bleach rate of 
IpHluorin in individual (growing, sporulating, and germinating) cells.

We have observed clear differences in $\mathrm{pH}_{\mathrm{i}}$ between $\mathrm{P}_{\mathrm{ptsG}^{-}}$ IpHluorin and sporulation-specific IpHluorin. It has been shown that within a growing population of $B$. subtilis cells, differentiation occurs (Veening et al., 2006a,b) and this may affect metabolic state and $\mathrm{pH}_{\mathrm{i}}$. This heterogeneity cannot be clearly monitored in batch without the use of more specific promoters or single cell observations. Also during spore germination such heterogeneity is seen (Smelt et al., 2008), so our results show the average of a germinating population.

During spore germination, the $\mathrm{pH}_{\mathrm{i}}$ increases due to release of protons (Swerdlow et al., 1981). This process follows the drop in $\mathrm{OD}_{600}$, and results from $\mathrm{H}_{2} \mathrm{O}$ uptake and release of DPA. Our results show that a $\Delta \mathrm{pH}$ is established rapidly. Such an increased $\mathrm{pH}$ can reactivate PGM, thus allowing the utilization of the spore's 3-PGA store (Magill et al., 1994).

Taken together, our results show accurate, long-term $\mathrm{pH}_{\mathrm{i}}$ monitoring in growing and sporulating $B$. subtilis cultures as well as during spore germination. The $\mathrm{pH}_{\mathrm{i}}$ of sporulating cells is as high as that of exponentially growing cells. This is particularly the case for the mother cell. The pre-spore $\mathrm{pH}_{\mathrm{i}}$ drops to $\mathrm{pH}=6.0$, however. The $\mathrm{P}_{\mathrm{pts}}$-IpHluorin strain can be used for many experiments

\section{REFERENCES}

Barton, J. K., Den Hollander, J. A., Lee, T. M., MacLaughlin, A., and Shulman, R. G. (1980). Measurement of the internal $\mathrm{pH}$ of yeast spores by $31 \mathrm{P}$ nuclear magnetic resonance. Proc. Natl. Acad. Sci. U.S.A. 77, 2470-2473. doi: 10.1073/pnas.77.5.2470

Booth, I. R. (1985). Regulation of cytoplasmic $\mathrm{pH}$ in bacteria. Microbiol. Rev. 49, 359-378.

Botella, E., Fogg, M., Jules, M., Piersma, S., Doherty, G., Hansen, A., et al. (2010). pBaSysBioII: an integrative plasmid generating gfp transcriptional fusions for high-throughput analysis of gene expression in Bacillus subtilis. Microbiology (UK) 156, 1600-1608. doi: 10.1099/mic.0.035758-0

Breeuwer, P., Drocourt, J., Rombouts, F. M., and Abee, T. (1996). A novel method for continuous determination of the intracellular $\mathrm{pH}$ in bacteria with the internally conjugated fluorescent probe 5 (and 6-)-carboxyfluorescein succinimidyl ester. Appl. Environ. Microbiol. 62, 178-183.

Brul, S., and Coote, P. (1999). Preservative agents in foods. Mode of action and microbial resistance mechanisms. Int. J. Food Microbiol. 50, 1-17. doi: 10.1016/S01681605(99)00072-0

Bulthuis, B. A., Koningstein, G. M., Stouthamer, A. H., and Van Verseveld, H. W. (1993). The relation of proton motive force, adenylate energy charge and phosphorylation potential to the specific growth rate and efficiency of energy transduction in Bacillus licheniformis under aerobic growth conditions. Antonie Van Leeuwenhoek 63, 1-16. doi: 10.1007/BF00871725

Casadaban, M. J., and Cohen, S. N. (1980). Analysis of gene control signals by DNA fusion and cloning in Escherichia coli. J. Mol. Biol. 138, 179-207. doi: 10.1016/0022-2836 (80)90283-1

Cortezzo, D. E., Setlow, B., and Setlow, P. (2004). Analysis of the action of compounds that inhibit the germination of spores of Bacillus species. J. Appl. Microbiol. 96, 725741. doi: 10.1111/j.1365-2672.2004. 02196.x

Cruciat, C.-M., Ohkawara, B., Acebron, S. P., Karaulanov, E., Reinhard, C., Ingelfinger, D., et al. (2010). Requirement of prorenin receptor and vacuolar $\mathrm{H}+$-ATPase-mediated acidification for Wnt signaling. Science $327,459-463$. doi: $10.1126 /$ science. 1179802

Eichenberger, P., Fujita, M., Jensen, S. T., Conlon, E. M., Rudner, D. Z., Wang, S. T., et al. (2004). The program of gene transcription for a single differentiating cell type during sporulation in Bacillus subtilis. PLoS Biol. 2:e328. doi: 10.1371/journal.pbio.0020328

Ferguson, W. J., Braunschweiger, K. I., Braunschweiger, W. R., Smith, J. R., McCormick, J. J., Wasmann,

where the $\mathrm{pH}_{\mathrm{i}}$ needs to be measured in cells growing on glucose, without the need for additional inducers like IPTG. Also, antibiotics are not strictly necessary. The sporulation-specific IpHluorin-expressing strains may give more insight in compartmentalization during sporulation, while the $\mathrm{P}_{\mathrm{sspE}}$-IpHluorin strain may also help understanding spore germination characteristics in the presence of potential outgrowth inhibitors such as the WOAs sorbic acid and acetic acid.

Clearly, because not all cells are in exactly the same state, these data represent the average value of the $\mathrm{pH}_{\mathrm{i}}$ in the population studies. To analyze the heterogeneity single-spore $\mathrm{pH}_{\mathrm{i}}$ measurements are needed. Currently we are extending our single cell live imaging tool "SporeTracker" (Pandey et al., 2013) to that end.

\section{ACKNOWLEDGMENTS}

Tanneke den Blaauwen and Jolanda Verheul are thanked for usage of and assistance with the microscopy facilities of the department of Molecular Cytology at the University of Amsterdam. Frans Klis and Gertien Smits are acknowledged for critically reading initial versions of the manuscript. Alex Ter Beek and Janneke Wijman are acknowledged for initial experiments with pHluorin and many stimulating discussions on Bacillus subtilis acid stress physiology.

C. C., etal. (1980). Hydrogen ion buffers for biological research. Anal. Biochem. 104, 300-310. doi: 10.1016/0003-2697(80)90079-2

Good, N. E., Winget, G. D., Winter, W., Connolly, T. N., Izawa, S., and Singh, R. M. (1966). Hydrogen ion buffers for biological research. Biochemistry 5, 467-477. doi: 10.1021/ bi00866a011

Hilbert, D. (2004). Compartmentalization of gene expression during Bacillus subtilis spore formation. Microbiol. Mol. Biol. 68, 234-262. doi: 10.1128/MMBR.68.2.234-262.2004

Joseph, P., Fantino, J. R., Herbaud, M. L., and Denizot, F. (2001). Rapid orientated cloning of a shuttle vector allowing modulated gene expression in Bacillus subtilis. FEMS Microbiol. Lett. 205, 91-97. doi: 10.1111/j.15746968.2001.tb10930.x

Keijser, B. J. F., Ter Beek, A., Rauwerda, H., Schuren, F., Montijn, R. Van der Spek, H., et al. (2007). Analysis of temporal gene expression during Bacillus subtilis spore germination and outgrowth. J. Bacteriol. 189, 3624-3634 doi: 10.1128/JB.01736-06

Koppelman, C.-M., Aarsman, M. E. G., Postmus, J., Pas, E., Muijsers, A. O., Scheffers, D.-J., et al. (2004). R174 of Escherichia coli FtsZ is involved in membrane interaction and protofilament bundling, and is essential for cell division. Mol. Microbiol. 51, 645-657. doi: 10.1046/j.13652958.2003.03876.x
Krulwich, T. A., Ito, M., Hicks, D. B., Gilmour, R., and Guffanti, A. A. (1998). pH homeostasis and ATP synthesis: studies of two processes that necessitate inward proton translocation in extremely alkaliphilic Bacillus species. Extremophiles 2, 217-222. doi: 10.1007/s007920050063

Krulwich, T. A., Sachs, G., and Padan, E. (2011). Molecular aspects of bacterial $\mathrm{pH}$ sensing and homeostasis. Nat. Rev. Microbiol. 9, 330-343. doi: 10.1038/nrmicro2549

Kunst, F., and Rapoport, G. (1995). Salt stress is an environmental signal affecting degradative enzyme synthesis in Bacillus subtilis. J. Bacteriol. 177, 2403-2407.

Leuschner, R. G., and Lillford, P. J. (2000). Effects of hydration on molecular mobility in phase-bright Bacillus subtilis spores. Microbiology (UK) 146, 49-55.

Lewis, P. J., and Marston, A. L. (1999). GFP vectors for controlled expression and dual labelling of protein fusions in Bacillus subtilis. Gene 227, 101-110. doi: 10.1016/S0378-1119 (98)00580-0

Magill, N. G., Cowan, A. E., Koppel, D. E., and Setlow, P. (1994). The internal $\mathrm{pH}$ of the forespore compartment of Bacillus megaterium decreases by about $1 \mathrm{pH}$ unit during sporulation. J. Bacteriol. 176, 2252-2258.

Magill, N. G., Cowan, A. E., LeyvaVazquez, M. A., Brown, M., Koppel, D. E., and Setlow, P. (1996). 
Analysis of the relationship between the decrease in $\mathrm{pH}$ and accumulation of 3-phosphoglyceric acid in developing forespores of Bacillus species. J. Bacteriol. 178, 2204-2210.

Miesenböck, G., De Angelis, D. A., and Rothman, J. E. (1998). Visualizing secretion and synaptic transmission with $\mathrm{pH}$-sensitive green fluorescent proteins. Nature 394, 192-195. doi: $10.1038 / 28190$

Orij, R. (2010). On the Intracellular $p H$ of Baker's Yeast. Ph.D. thesis, University of Amsterdam, Amsterdam.

Orij, R., Brul, S., and Smits, G. J. (2011). Intracellular $\mathrm{pH}$ is a tightly controlled signal in yeast. Biochim. Biophys. Acta 1810, 933-944. doi: 10.1016/j.bbagen.2011.03.011

Orij, R., Postmus, J., Ter Beek, A., Brul, S., and Smits, G. J. (2009). In vivo measurement of cytosolic and mitochondrial $\mathrm{pH}$ using a $\mathrm{pH}$ sensitive GFP derivative in Saccharomyces cerevisiae reveals a relation between intracellular $\mathrm{pH}$ and growth. Microbiology (UK) 155, 268-278. doi: 10.1099/mic.0.022038-0

Ozbudak, E. M., Thattai, M., Kurtser, I., Grossman, A. D., and Van Oudenaarden, A. (2002). Regulation of noise in the expression of a single gene. Nat. Genet. 31, 69-73. doi: 10.1038/ng869

Padan, E., and Schuldiner, S. (1987). Intracellular $\mathrm{pH}$ and membrane potential as regulators in the prokaryotic cell. J. Membr. Biol. 95, 189-198. doi: 10.1007/BF01869481

Pandey, R., Ter Beek, A., Vischer, N. O. E., Smelt, J., Brul, S., and Manders, E. M. M. (2013). Live cell imaging of germination and outgrowth of individual Bacillus subtilis spores; the effect of heat stress quantitatively analyzed with SporeTracker. PLoS ONE 8:e58972. doi: 10.1371/journal.pone.0058972

Russell, J. B., and Diez-Gonzalez, F. (1998). The effects of fermentation acids on bacterial growth. $A d v$. Microb. Physiol. 39, 205-234. doi: 10.1016/S0065-2911(08)60017-X

Setlow, B., and Setlow, P. (1980). Measurements of the $\mathrm{pH}$ within dormant and germinated bacterial spores. Proc. Natl. Acad. Sci. U.S.A. 77, 2474 2476. doi: 10.1073/pnas.77.5.2474

Shioi, J. I., Matsuura, S., and Imae, Y. (1980). Quantitative measurements of proton motive force and motility in Bacillus subtilis. J. Bacteriol. 144, 891-897.
Singh, R. P., Setlow, B., and Setlow, P. (1977). Levels of small molecules and enzymes in the mother cell compartment and the forespore of sporulating Bacillus megaterium. J. Bacteriol. 130, 1130-1138.

Slonczewski, J. L., Fujisawa, M., Dopson, M., and Krulwich, T. A. (2009). Cytoplasmic $\mathrm{pH}$ measurement and homeostasis in bacteria and archaea. Adv. Microb. Physiol. 55, 1-74. doi: 10.1016/S0065-2911(09)05501-5

Smelt, J. P. P. M., Bos, A. P., Kort, R., and Brul, S. (2008). Modelling the effect of sub(lethal) heat treatment of Bacillus subtilis spores on germination rate and outgrowth to exponentially growing vegetative cells. Int. J. Food Microbiol. 128, 3440. doi: 10.1016/j.ijfoodmicro. 2008 . 08.023

Steil, L., Serrano, M., Henriques, A. O., and Völker, U. (2005). Genome-wide analysis of temporally regulated and compartment-specific gene expression in sporulating cells of Bacillus subtilis. Microbiology (UK) 151, 399420. doi: 10.1099/mic.0.27493-0

Stragier, P., Bonamy, C., and KarmazynCampelli, C. (1988). Processing of a sporulation sigma factor in Bacillus subtilis: how morphological structure could control gene expression. Cell 52, 697-704. doi: 10.1016/00928674(88)90407-2

Stratford, M., Plumridge, A., Nebevon-Caron, G., and Archer, D. B. (2009). Inhibition of spoilage mould conidia by acetic acid and sorbic acid involves different modes of action, requiring modification of the classical weak-acid theory. Int. J. Food Microbiol. 136, 37-43. doi: 10.1016/j.ijfoodmicro.2009.09.025

Sunde, E. P., Setlow, P., Hederstedt, L., and Halle, B. (2009). The physical state of water in bacterial spores. Proc. Natl. Acad. Sci. U.S.A. 106, 19334-19339. doi: 10.1073/ pnas.0908712106

Swerdlow, B. M., Setlow, B., and Setlow, P. (1981). Levels of $\mathrm{H}+$ and other monovalent cations in dormant and germinating spores of Bacillus megaterium. J. Bacteriol.148, 20-29.

Ter Beek, A. S. (2009). Weak Organic Acid Stress in Bacillus subtilis. Ph.D. thesis, University of Amsterdam, Amsterdam.

Ter Beek, A. S., and Brul, S. (2010). To kill or not to kill Bacilli: opportunities for food biotechnology. Curr.
Opin. Biotechnol. 21, 168-174. doi 10.1016/j.copbio.2010.03.014

Ugurbil, K., Rottenberg, H., Glynn, P., and Shulman, R. G. (1978). 31P nuclear magnetic resonance studies of bioenergetics and glycolysis in anaerobic Escherichia coli cells. Proc. Natl. Acad. Sci. U.S.A. 75, 2244-2248. doi: 10.1073/pnas.75.5.2244

Ullah, A., Orij, R., Brul, S., and Smits, G. J. (2012). Quantitative analysis of the modes of growth inhibition by weak organic acids in yeast. Appl. Environ. Microbiol. 78, 8377-8387. doi: 10.1128/AEM.02126-12

Van Melis, C. C. J., Nierop Groot, M. N., and Abee, T. (2011). Impact of sorbic acid on germinant receptordependent and -independent germination pathways in Bacillus cereus. Appl. Environ. Microbiol. 77, 25522554. doi: 10.1128/AEM.02520-10

Veening, J., Smits, W. K., Hamoen, L. W., Jongbloed, J. D. H., and Kuipers, O. P. (2004). Visualization of differential gene expression by improved cyan fluorescent protein and yellow fluorescent protein production in Bacillus subtilis. Appl. Environ. Microbiol. 70, 68096815. doi: 10.1128/AEM.70.11.68096815.2004

Veening, J.-W., Hamoen, L. W., and Kuipers, O. P. (2005). Phosphatases modulate the bistable sporulation gene expression pattern in Bacillus subtilis. Mol. Microbiol. 56, 1481-1494. doi: 10.1111/j.13652958.2005.04659.x

Veening, J.-W., Smits, W. K., Hamoen, L. W., and Kuipers, O. P. (2006a) Single cell analysis of gene expression patterns of competence development and initiation of sporulation in Bacillus subtilis grown on chemically defined media. $J$. Appl. Microbiol.101, 531-541. doi: 10.1111/j.1365-2672.2006.02911.x

Veening, J. W., Kuipers, O. P. Brul, S., Hellingwerf, K. J., and Kort, R. (2006b). Effects of phosphorelay perturbations on architecture, sporulation and spore resistance in biofilms of Bacillus subtilis. J. Bacteriol. 188, 3099-3109. doi: 10.1128/JB.188.8.3099-3109.2006

Veening, J.-W., Stewart, E. J., Berngruber, T. W., Taddei, F., Kuipers, O. P., and Hamoen, L. W. (2008). Bet-hedging and epigenetic inheritance in bacterial cell development Proc. Natl. Acad. Sci. U.S.A.
105, 4393-4398. doi: 10.1073/ pnas.0700463105

Vojinovic, V., and Von Stockar, U. (2009). of uncertainties in $\mathrm{pH}, \mathrm{pMg}$, activity coefficients, metabolite concentrations, and other factors on the analysis of the thermodynamic feasibility of metabolic pathways. Biotechnol. Bioeng. 103, 780-795. doi: 10.1002/bit.22309

Wang, S. T., Setlow, B., Conlon, E. M., Lyon, J. L., Imamura, D., Sato, T., et al. (2006). The forespore line of gene expression in Bacillus subtilis. J. Mol. Biol. 358, 16-37. doi: 10.1016/j.jmb.2006.01.059

Wax, R., and Freese, E. (1968). Initiation of the germination of Bacillus subtilis spores by a combination of compounds in place of L-alanine. $J$. Bacteriol. 95, 433-438.

Young, B. P., Shin, J. J. H., Orij, R., Chao, J. T., Li, S. C., Guan, X. L., et al. (2010). Phosphatidic acid is a $\mathrm{pH}$ biosensor that links membrane biogenesis to metabolism. Science 329, 1085-1088. doi: 10.1126/science. 1191026

Conflict of Interest Statement: The authors declare that the research was conducted in the absence of any commercial or financial relationships that could be construed as a potential conflict of interest.

Received: 05 April 2013; accepted: 30 May 2013; published online: 18 June 2013. Citation: van Beilen JWA and Brul S (2013) Compartment-specific pH monitoring in Bacillus subtilis using fluorescent sensor proteins: a tool to analyze the antibacterial effect of weak organic acids. Front. Microbiol. 4:157. doi: 10.3389/ fmicb.2013.00157

This article was submitted to Frontiers in Microbial Physiology and Metabolism, a specialty of Frontiers in Microbiology. Copyright (c) 2013 van Beilen and Brul. This is an open-access article distributed under the terms of the Creative Commons Attribution License, which permits use, distribution and reproduction in other forums, provided the original authors and source are credited and subject to any copyright notices concerning any third-party graphics etc. 